\title{
Determining the tax base for non-building structures in real estate tax in the light of the relationship between tax law and the balance sheet accounts regulations
}

\author{
Ustalanie podstawy opodatkowania budowli \\ w podatku od nieruchomości w świetle związków \\ prawa podatkowego z prawem bilansowym
}

\begin{abstract}
The subject of this article is an analysis of legal regulations on the tax base in a real estate tax for non-building structures in the situation of making only a balance sheet depreciation of fixed assets that are non-building structures and capitalizing indirect costs in the initial value of the fixed asset of the non-building structure which is the subject of taxation. The author analysed a relationship between tax law and balance sheet law. Against this background, with regard to the interpretation of regulations on the taxation of non-building structures, he identified certain problems, which are related to ambiguous results of the abovementionned interpretation and the need to derive the meaning of concepts in other
\end{abstract}


branches of law. The conducted analysis has led to the conclusion that provisions regulating the tax base in a real estate tax with regard to non-building structures, like other provisions of the Act on Local Taxes and Charges, are ambiguous and they require legislative changes.

Keywords: real estate tax; tax base; non-building structure; depreciation; fixed assets; initial value.

Streszczenie. Przedmiotem opracowania jest analiza regulacji prawnych dotyczących podstawy opodatkowania w podatku od nieruchomości dla budowli w sytuacji dokonywania wyłącznie amortyzacji bilansowej środków trwałych będących budowlami oraz skapitalizowania kosztów pośrednich w wartości początkowej środka trwałego budowli, będącej przedmiotem opodatkowania. Autor przeprowadził analizę w kontekście związków łączących prawo podatkowe z prawem bilansowym. Na tle tych związków z interpretacją przepisów dotyczących opodatkowania budowli powstają bowiem problemy związane z niejednoznacznymi wynikami wykładni oraz potrzebą poszukiwania znaczenia pojęć w innych gałęziach prawa. Przeprowadzona analiza doprowadziła do wniosku, że przepisy regulujące podstawę opodatkowania w podatku od nieruchomości w zakresie budowli, podobnie jak pozostałe regulacje ustawy o podatkach i opłatach lokalnych, cechuje niejednoznaczna treść przepisów wymagająca zmian legislacyjnych.

Słowa kluczowe: podatek od nieruchomości; podstawa opodatkowania; budowla; amortyzacja; środki trwałe; wartość początkowa.

\section{Introduction}

The doctrine has developed a detailed catalogue of features distinguishing tax law ${ }^{1}$, one of the most important of which is the relationship between the standards of tax law, and other branches of law, in particular private ${ } \mathrm{aw}^{2}$. Independently of relationships with private law, tax law is also characterised by having connections with other branches of law, including with a broadly understood public law.

B. Brzeziński, Wstęp do nauki prawa podatkowego, Toruń 2003, pp. 149-156.

This is discussed in more detail in B. Brzeziński, Prawo podatkowe. Zagadnienia teorii i praktyki, Toruń 2017, p. 374 et seq. 
Such relations between branches of law are exemplified by regulations of a real estate tax in respect of the subject and an object of taxation. This theme has been analysed in the doctrine. At the same time, the institutional interrelations between different branches of law also occur in case of the tax base in a real estate tax. It should also be emphasised that regulations concerning the object of a real estate taxation were often subject to: amendments in connection with the need to specify the content of regulations, as well as to decisions of the Constitutional Tribunal. However, in case of the tax base, changes in legal regulations were relatively rare and they have not usually refered to the essence of the institutions. This may indicate that an application of regulations concerning the tax base in the real estate tax does not raise any significant doubts and thus it meets the required quality standards of regulations, implementing, inter alia, the constitutional principle of specificity. However, this view should be verified, including in the context of links between tax law and balance sheet law. Against this background, with regard to the interpretation of regulations on the taxation of non-building structures, certain problems arise, which are related to ambiguous results of an interpretation of these concepts and the need to search for the meaning of these concepts in other branches of law. The imprecise content of tax regulations and their structure seem to be the source of doubt.

In this article the author analysed legal regulations concerning the tax base in real estate tax for non-building structures in order to evaluate them in order to supplement the existing research on the tax base in a real estate tax, as well as to suggest possible legislative changes. This research is based on a dogmatic and legal analysis, referring also to non-binding legal regulations. The study also refers to the jurisprudence of administrative courts. 


\section{The concept of a "non-building structure" in real estate tax and under the Construction Law}

Pursuant to Article 2 (1) (3) of the Act of 12 January 1991 on Local Taxes and Charges $^{3}$, non-building structures or parts thereof related to the conducted business activity are subject to a real estate tax. Pursuant to Article 1a (1)(2) of the Act on Local Taxes and Charges, a non-building structure is, in turn, a built structure within the meaning of the provisions of the Construction Law which is not a building or an element of a street furniture, as well as a construction facility within the meaning of Building Law related to a built structure, which ensures the possibility of utilising the structure in accordance with its intended purpose.

Therefore, the analysed structures constitute non-building structures only if they are a built structure or a construction facility within the meaning of the Construction Law. Pursuant to Article 3(1) of the Construction Law of 7 July $1994^{4}$ (as it was in force until 28 June 2015) a built structure was a building together with technical installations and equipment, a non-building structure constituting a complete object from a technical and utilitarian point of view, together with installations and equipment, and an element of street furniture. Pursuant to Article 3(1)(b) of the Construction Law (in the wording in force from 1 January 2016) a built structure should be understood as a non-building structure or an element of a street furniture together with installations ensuring the possibility of using the structure in accordance with its intended use, erected with the use of construction products. The above regulations raise doubts as to the definition of a non-building structure. This is owing to the fact that the provisions of the Tax Act define a non-building structure as a built structure, referring to the Construction Law, while they also include a non-building structure under the category of a built structure

3 Consolidated text: Dz.U. [Polish Journal of Laws] of 2019, poz. [item] 1170 with subsequent amendments, hereinafter "LTCA" or "Act on Local Taxes and Charges".

4 Consolidated text: Dz.U. of 2013, poz. 14091170 with subsequent amendments, hereinafter "CL” or "Construction Law". 
(constituting, until 28 June 2015, a complete object from the technical and utilitarian point of view, thus including together with installations and equipment).

The statutory definition of a non-building structure for the purposes of a real estate tax, regardless of legislative changes, should therefore be qualified as defining idem per idem ${ }^{5}$. The interpretation should also refer to Article 3(3) of the Construction Law, according to which the concept of a non-building structure should particularly include: airports, roads, railway lines, bridges, flyovers, overpasses, tunnels, culverts, technical networks, standalone antenna masts, standalone advertising equipment fixed to the ground, earthworks, defence fortifications, protective structures, hydrotechnical structures, tanks, standalone industrial installations or technical equipment, sewage treatment plants, landfills, water treatment plants, retaining structures, pedestrian underpasses and overpasses, infrastructure development networks, sports structures, cemeteries, monuments, as well as construction parts of technical equipment (boilers, industrial furnaces, wind power plants, and other equipment), and foundations for machinery and equipment, as technically separate parts of items constituting the complete utilitarian object. Pursuant to Article 3(9)(b) of the Construction Law, a construction facility is recognised as a technical equipment ensuring the possibility of utilising the facility in accordance with its intended use, such as connections and installation equipment, including sewage treatment or collection, driveways, fences, parking lots, and garbage dump yards.

Taking into account the above regulations, in accordance with the current case-law of administrative courts, the non-building structures within the meaning of Article 1a (1)(2) of LTCA are, therefore, all the built structures listed, for example, in Article 3(3) of the Construction Law and those built structures which are similar to them. However, taxation of objects which are not enumerated in Article 3(3) of the Construction Law and other provisions of this Act, and whose construction, charac-

5 W. Morawski [in:] T. Brzezicki, K. Lasiński-Sulecki, W. Morawski (ed.), J. Wantoch-Rekowski, Ustawa o podatkach i opłatach lokalnych. Komentarz, Gdańsk 2009, p. 56 et seq. 
ter, and purpose differ from those enumerated by the legislator, violates the principle of specificity and the principle of statutory determination of the subject of public-law contributions, resulting from Articles 2 and 217 of the Constitution of the Republic of Poland ${ }^{6}$. It should be emphasised that the above finding was also formulated in the judgment of the Constitutional Tribunal of 13 September $2011^{7}$, in which it was stated that "nonbuilding structures within the meaning of the Act on Local Taxes and Charges may be considered:

1. only as structures listed expressis verbis in Article 3(3) of the Construction Law, in other provisions of this Act or in an annex thereto, which are, together with installations and equipment, a built structure referred to in Article 3(1) (b) of the Construction Law, i.e. on condition that they constitute a complete object from a technical and utilitarian point of view,

2. only technical equipment characterised in Article 3(9) of the Construction Law or in other provisions of this Act or in the annex thereto".

The Constitutional Tribunal stated that although the legislator's use of the definition of a non-building structure does not raise any objections to the extent to which it is used for the purposes of the construction law, the possibility of applying it in the same way under the tax law should be excluded.

A non-building structure within the meaning of the Act on Local Taxes and Charges should, therefore, be considered as a built structure which has been clearly indicated in the catalogue of structures listed $e x$ pressis verbis in the Construction Law or in other provisions of the Construction Law. The same concept would apply to a construction facility. At present, this thesis is undisputed and it is uniformly accepted in the jurisprudence of administrative courts and by the representatives of the doctrine.

6 E.g. Supreme Administrative Court judgment of 7 October 2009, II FSK 635/08, Central Database of Administrative Court Judgments (CBOSA), and the Supreme Administrative Court judgment of 9 April 2013, II FSK 3004/2011, CBOSA.

7 P 33/09, OTK-A 2011/ 7, item 71. 
On the margin of the main considerations, one should relate to the lack of an acceptance of the "cascading" way of defining terms in the tax law in relation to a non-building structure, adopted by the tax legislator, with additional reference to the categories of built structures provided for in the annexes to the Construction Law $\mathrm{Act}^{8}$. Such a way of defining terms in tax law should be assessed negatively, not only from the point of view of the difficulties it creates to taxpayers who are interpreting these regulations, but also because these regulations raise serious concerns with respect to their compliance with the principles of correct legislation ${ }^{9}$ in the light of the statement of reasons for the aforementioned judgment of the Constitutional Tribunal of 13 September 2011 and the judgment of the Constitutional Tribunal of 13 December $2017^{10}$.

\section{Legal regulations governing the determination of the tax base for non-building structures}

Without making of the analysis of the doctrine's views on the construction of the tax, it must be concluded that there is a consensus that the construction of any tax consists of at least four basic elements. These are: a subject of taxation (an entity liable to pay tax), an object of taxation (a situation to which the liability to pay tax is related), a tax base (a quantity or value of the object), and a tax rate (a coefficient used to calculate the tax amount by a reference to the tax base ${ }^{11}$. The tax base is therefore a significant

8 See the signalling decision of the Supreme Administrative Court of 29 May 2018, II FSK 2983/17, CBOSA. Cf. K. Radzikowski, Ciq̨g dalszy sporów o definicję budowli jako przedmiotu opodatkowania podatkiem od nieruchomości - casus elektrowni wiatrowych, „Zeszyty Naukowe Naczelnego Sadu Administracyjnego” 2017, No 5, pp. 36-60.

9 See also the transcript of a hearing before the Constitutional Tribunal in case SK 48/15 http://trybunal.gov.pl/postepowanie-i-orzeczenia/wokanda/art/2017-podatki-i-oplatylokalne-zasady-ustalania-podatku-od-nieruchomosci.

10 SK 48/15 OTK-A 2018/2.

11 L. Kurowski, Wstęp do nauki prawa finansowego, Warszawa 1982, pp. 157-162; K. Ostrowski, Prawo finansowe. Zarys ogólny, Warszawa 1970, p. 144; N. Gajl, Finanse i prawo finansowe, Warszawa 1992, pp. 230-243; J. Harasimowicz, Finanse i prawo finansowe, Warszawa 1988, pp. 114-118; M. Weralski, Finanse publiczne i prawo finansowe, Warszawa 1984, p. 242. 
component of the tax structure, as it is a numerical expression of the subject of taxation, while it is a so-called incidental component, because it may not be present in the tax structure ${ }^{12}$. In particular, the tax base does not exist in some, usually optional, forms of taxation (e.g. flat-rate income taxation).

In accordance with Article 4(1)(3) of LTCA, the tax base for nonbuilding structures or their parts connected with conducting business activity is the value referred to in income tax regulations, determined on $1^{\text {st }}$ January of the tax year, constituting the basis for calculating depreciation in that year, not decreased by depreciation write-offs, and in the case of fully depreciated non-building structures, their value of $1^{\text {st }}$ January of the year in which the last depreciation write-off was made. These regulations seem to introduce a rational solution which binds the construction of a real estate tax and income taxes, influencing the cohesion of the tax system. The taxpayer must take into account the fact that the higher the depreciation value of a non-building structure which is a fixed asset is, affecting the reduction of the income tax amount, the higher is the tax base in the real estate tax. Pursuant to Article 4(5) of LTCA, if no depreciation writeoffs are made on the non-building structures or their parts referred to in section 1(3), the tax base is their market value which was determined by the taxpayer at a time when the tax obligation arises. With respect to the situation in which the tax obligation arose during the tax year, with regard to the real estate tax on non-building structures referred to in Article 4(1)(3) of LTCA, the tax base is the value constituting the basis for calculating depreciation as of the date when the tax obligation arose (Article 4 (3) of LTCA). Binding regulations also provide for modifications of a scope of leased non-building structures. Pursuant to Article 4(4) of LTCA, if the non-building structure referred to in section 1(3) of LTCA is subject to a leasing agreement and if depreciation write-offs are made by the lessee, in the event that it is taken over by the owner for the purpose of determining the tax base, the initial value should be adopted, i.e. the value

12 B. Brzeziński, Część III - prawo dochodów publicznych [in:] B. Brzeziński, T. Dębowska-Romanowska, M. Kalinowski, W. Wójtowicz (ed.), Prawo finansowe, Warszawa 1997, p. 164. 
before the conclusion of the first leasing agreement, updated and increased by the improvements made and not reduced by the repayment of the initial value.

The tax base is their market value determined of $1^{\text {st }}$ January of the tax year following the year in which the fixed assets had been improved or revalued, if the non-building structures or their parts have been improved or, in accordance with the income tax regulations, the fixed assets have been revalued in accordance with Article 4(6) of LTCA. The provisions of the Local Taxes and Charges Act also provide for procedural regulations related to the consequences of the taxpayer's failure to determine the tax base. Pursuant to Article 4(7) of the LTCA, if the taxpayer did not specify the value of the non-building structures referred to in Article 4(1)(3) and (5) of the LTCA or if he/she provides a value that does not correspond to the market value, the tax authority will appoint an expert to determine the value. If the taxpayer has not determined the value of the non-building structures referred to in Article 4(1) (3) (5) of the LTCA, or the value determined by an expert is at least $33 \%$ higher than the value determined by the taxpayer, the costs of determining the value by an expert shall be borne by the taxpayer.

The interpretation of the above regulations raises doubts concerning various aspects, including: an assessment of a situation in which the taxpayer will not simultaneously depreciate a non-building structure which is a fixed asset ${ }^{13}$, a possibility of verifying the value resulting from the records of fixed assets by the local tax authority, a significance of a revalua-

13 See e.g.: judgment of the Voivodeship Administrative Court in Łódź of 25 January 2018, I SA/Łd 810/16, Central Database of Administrative Court Judgments; judgment of the Voivodeship Administrative Court in Łódź of 5 December 2017, I SA/Łd 905/14, Central Database of Administrative Court Judgments; judgment of the Voivodeship Administrative Court in Poznań of 24 November 2017, I SA/Po 827/17, Central Database of Administrative Court Judgments; judgment of the Voivodeship Administrative Court in Łódź of 15 November 2017, I SA/Łd 802/17, Central Database of Administrative Court Judgments; judgment of the Voivodeship Administrative Court in Bydgoszcz of 24 October 2017, I SA/Bd 859/17, Central Database of Administrative Court Judgments; judgment of the Voivodeship Administrative Court in Szczecin of 8 March 2017, I SA/Sz 1192/17, Central Database of Administrative Court Judgments; judgment of the Voivodeship Administrative Court in Bydgoszcz of 15 February 2017, I SA/Bd 833/16, Central Database of Administrative Court Judgments. 
tion of fixed assets or a calculation of the value of the base for a nonbuilding structure which is part of a fixed asset ${ }^{14}$. The above issues were subject to analysis of the doctrine. Therefore, their synthetic description in this study does not seem advisable.

At the same time, a problem which has not been discussed in more details by the doctrine so far is the meaning of the term "depreciation" and the phrase "not making depreciation write-offs" used in the provisions regulating the tax base for a real estate tax. A much wider issue that arises in the background of the above problems is the relationship between tax law regulations and the balance sheet law.

\section{The meaning of the term "depreciation"}

For non-building structures, the real estate tax base is the value referred to in the income tax regulations ("the initial value of fixed assets"), determined as of the $1^{\text {st }}$ January of the tax year, constituting the basis for calculating depreciation in that year, not reduced by depreciation write-offs, and in the case of fully depreciated non-building structures - their value as of $1^{\text {st }}$ January of the year in which the last depreciation write-off was made. The concept of a depreciation is, therefore, of fundamental importance for determination of the real estate tax base for non-building structures. However, the problem is, that it is not uniform. The term is used in everyday language and has different meanings in the balance sheet law and in tax acts. The fact that in Article 4(1)(3) of the LTCA, the legislator referred to "the value referred to in the provisions on income taxes", which seems to indicate that the interpretation is limited to tax regulations only is not the decisive factor in resolving problems with the interpretation of provisions. While interpreting the provisions concerning the concept of a depreciation provided for in Article 4(5) read in conjunction with Article 4(1)(3) of the LTCA, one should, of course, consider that this term

14 This is discussed in more detail in: W. Morawski [in:] T. Brzezicki, K. LasińskiSulecki, O. Łunarski, P. Majka, W. Morawski (ed.), J. Wantoch-Rekowski, Podatek od nieruchomości w orzecznictwie sq̨ów administracyjnych. Komentarz. Linie interpretacyjne, Warsaw 2012, pp. 426-449. 
relates to a depreciation in Article 16a(1) of the Act of 15 February 1992 on corporate income $\operatorname{tax}^{15}$, and in Article 22a(1) of the Act of 26 July 1991 on personal income $\operatorname{tax}^{16}$ (the so-called "tax depreciation"). At the same time, the need arises to assess whether the term "depreciation" under the Act on Local Taxes and Charges also covers the concept of the socalled "balance sheet depreciation" provided for, inter alia, in Article 31(2) of the Accounting Act of 29 September $1994^{17}$. This problem arises in particular when the owner of a non-building structure (a local government unit) delivers it to another entity (a real estate taxpayer) and makes depreciation write-offs within the framework of balance sheet depreciation, while - at the same time - the owner of the non-building structure is not an income taxpayer, and does not make any depreciation write-offs from the value of the fixed asset which is a non-building structure, for the purposes of calculating the income $\operatorname{tax}^{18}$.

In the jurisprudence of administrative courts, there are two lines relating to the understanding of the term "depreciation" in the regulations of the Act on Local Taxes and Charges. The first line refers to a systemic interpretation of Article 4(5) of the LTCA according to which the term “depreciation” refers exclusively to tax depreciation, since Article 4(1)(3) of the LTCA refers to the value constituting a basis for calculating depreciation for tax purposes. Therefore, making depreciation write-offs on the basis of tax regulations precludes the determination of the value of a nonbuilding structure on the basis of its market value. If, on the other hand, balance sheet depreciation write-off is made under accounting regulations,

15 Consolidated text: Dz.U. of 2019, poz. 865 with subsequent amendments, hereinafter “a.c.i.t." or "Act on Corporate Income Tax".

16 Consolidated text: Dz.U. of 2019, poz. 1387 with subsequent amendments, hereinafter referred to as "a.p.i.t."

17 Consolidated text: Dz.U. of 2019, poz. 351 with subsequent amendments, hereinafter "a.a" or "Accounting Act".

18 This is discussed in more details in P. Majka, Podstawa opodatkowania budowli w podatku od nieruchomości - problem rodzaju podstawy opodatkowania [in:] B. Kucia-Guściora, M. Munnich, A. Zdunek, R. Zieliński (ed.), Stanowienie i stosowanie prawa podatkowego w Polsce. Granice opodatkowania, Lublin 2019. 
the value of such non-building structures for property tax purposes should be determined based on their market value ${ }^{19}$.

The second line of jurisprudence, which is represented by the judgment of the Voivodeship Administrative Court in Lublin of 26 February $2014,{ }^{20}$ is based on the assumption that a depreciation is an economic concept and means of a reduction in the value of a fixed asset due to its wear and tear. The registration of such events is based on the Accounting Act, and an obligation to apply the provisions of this Act applies both to entities applying the Corporate Income Tax Act and to those that do not apply it. In this sense, depreciation regulations are not only tax law regulations, according to which the statutory prerequisite for the application of market value for the taxation of non-building structures in real estate tax is not making depreciation write-offs, but also balance sheet law regulations related to accounting depreciation.

In resolving the above problem, it should be recognised that the interpretation of Article 4(5) read in conjunction with Article 4(1)(3) of the LTCA indicates that the term "depreciation write-offs" covers both tax and balance sheet depreciation. Thus, the content of Article 4(5) of the LTCA leads to the conclusion that the statutory prerequisite for adopting market value as the tax base for a non-building structure instead of the initial value is not making any depreciation write-offs. In particular, referring to the linguistic interpretation, there are no grounds to infer from the phrase "value referred to in the provisions on income taxes" which can be found in Article 4(1)(3) of the LTCA that only depreciation for income tax purposes precludes the application of Article 4(5) of the LTCA. The value referred to in the provisions on income taxes is the "initial value" used by the legislator in the Accounting Act. The close relationship between balance sheet and tax regulations also results directly from the provisions of the Act on Corporate Income Tax (a.c.i.t.). For example, Article 9(1) of the a.c.i.t. obliged of taxpayers to keep accounting records in ac-

19 The judgment of the Voivodeship Administrative Court in Rzeszów of 20 February 2018, I SA/Rz 6/18, CBOSA, and the Supreme Administrative Court judgment of 19 December 2018, II FSK 2029/18, CBOSA. 
cordance with separate regulations for the purpose of calculating, among others, the tax base. Thus, there is no justification to distinguish these two types of depreciation by provoking different effects for them with respect to the tax base for non-building structures. The aforementioned differences between the two types of depreciation (e.g. referring to the starting date, rates or depreciation period) do not affect the fact that the legislator adopted the "initial value" of the fixed asset as the tax base in the real estate tax. On the other hand, there is no doubt that the two types of depreciation are linked and that there is a "starting value" in both of them from which the depreciation write-off is made.

It should be noted that the legislator did not directly use the term "depreciation for tax purposes" in the Act on Local Taxes and Charges. However, the act contains a reference to the "initial value" referred to in the provisions of the Act on Income Taxes, which further specifies in Article 4(1)(3) of the LTCA that the "basis for calculating depreciation" is not limited to "tax depreciation". At the same time, it is only seemingly correct to claim that the legislator did not have to refer again to the regulations on income tax in this part of the provision. It should be noted that the analysis of other provisions of the Act on Local Taxes and Charges leads to the conclusion that the legislator, wishing to refer to the provisions of a specific Act, always mentions its title in the wording of the provisions (e.g. Article $1 \mathrm{a}(3 \mathrm{a}),(4)$, Article $1 \mathrm{a}(2)(3)$, Article $1 \mathrm{a}(3)$, Article $1 \mathrm{~b}(2)$ of the LTCA. However, when it does not refer to a specific act, but to a group of provisions regulating a given issue, it clearly indicates this in the content of the provision (e.g. Article 1a(2) of the LTCA providing for "the provisions of the Construction Law", and Article 2(3)(4) of the LTCA referring to "provisions on public roads"). Therefore, the interpretation cannot ignore the fact that the interpreted regulations use only the term "income tax regulations", which leaves an open question whether the scope of this term also includes regulations of the Accounting Act.

At the same time, it should be questioned whether the interpretation of the above regulations refers to the result of an external systemic interpretation based on Article 3(1) and (2) of the Act of 29 August 1997 - Tax Ordi- 
nance $^{21}$. This Ordinance contains the definition of "tax acts" and "tax law provisions" and these definitions are recognised in the case-law as not including the Accounting Act, which entails an order to exclude its provisions from the mechanism of determining the tax amount ${ }^{22}$. It is erroneous to base the interpretation of the disputed provisions of the Local Taxes and Charges Act on definitions from other legal acts which are not of a universal nature. Since the glossary of the Tax Ordinance contains definitions used exclusively for the interpretation of the provisions of the Tax Ordinance itself ${ }^{23}$, there is no basis for excluding provisions of the Accounting Act to determine the tax base in real estate tax when the content of the Income Tax Acts directly refers to that Act.

Justifying the claim about the broader meaning of the reference to the provisions on income taxes in Article 4(1)(3) of the LTCA, it should be emphasised that in the previous jurisprudence a similar problem had arisen regarding an interpretation of the term "tax law provisions” in 2005 in the Tax Ordinance that provides taxpayers with written information on the scope and manner of applying tax law in individual cases. The question was should the term "tax law provisions" be understood exclusively as provisions of tax law, i.e. provisions of tax acts and provisions of executive acts issued on their basis (pursuant to Article 3(2) of the Tax Ordinance), or as all provisions containing legal norms concerning the issue of tax liabilities (in this case it was the regulation of the Council of Ministers of 5 September 1995 on the establishment of a special economic zone in Mielec $^{24}$ ). The court resolved the issue rightly recognizing that the notion

21 Consolidated text: Dz.U. of 2019, poz. 900 with subsequent amendments, hereinafter "TO" or "Tax Ordinance".

22 Judgment of the Voivodeship Administrative Court in Rzeszów of 20 February 2018, I SA/Rz 6/18, CBOSA.

23 See B. Brzeziński (ed.), H. Filipczyk, M. Kalinowski (ed.), K. Lasiński-Sulecki, M. Masternak, W. Morawski, A. Nita, A. Olesińska (ed,), J. Orłowski, E. Prejs, J. Pustuł, Ordynacja podatkowa. Komentarz praktyczny, Gdańsk 2015, p. 25. Part of the doctrine also points to the universal nature of the terms from the glossary of the Tax Ordinance, at the same time pointing out that the scope of "tax law regulations" includes regulations of other acts than tax acts, provided that they concern elements of the legal construction of a tax (R. Mastalski [in:] B. Adamiak, J. Borkowski, R. Mastalski, J. Zubrzycki, Ordynacja podatkowa. Komentarz, Wrocław 2016, p. 35).

Dz.U. No 107, poz. 526 with subsequent amendments. 
of tax law should be understood as all legal norms, both statutory ones and those issued on the basis of statutory authorisation, which regulate all construction elements, i.e. objective and subjective elements of $\operatorname{tax}^{25}$. The above reasoning, which assumes the necessity to take into account a broader understanding of the meaning of the term "tax provision" in the course of interpreting the regulations, in connection with the necessary assessment of the content of the analysed regulation, should also be referred to the interpretation of the term "income tax provisions" in the Act on Local Taxes and Charges. Therefore, these will not only include the provisions contained in Acts on income taxes, but also regulations to which they refer, including the Accounting Act, which relates to the determination of the tax base.

Therefore, there are no grounds for rejecting the regulations of the Accounting Act with regard to institutions which are convergent while interpreting Article 4(1)(3) of the LTCA. In particular, within the framework of a systemic interpretation, there are no grounds for considering that the regulations of the Accounting Act exclude determination of the type of tax base. When applying the external systemic interpretation to solve the problem of depreciation type, one should refer to the provisions of the Accounting Act as an act regulating the depreciation of fixed assets. This interpretation, in turn, results in the convergence of the terms "depreciation" and "initial value", which are relevant for both tax and balance sheet depreciation. Importantly, it seems that the term "depreciation" is specific for economic terminology (depreciation is an economic concept meaning the gradual loss of value of fixed assets due to their wear and tear) and has its source in the balance sheet (accounting) regulations, which justifies the use of the provisions of the Accounting Act when applying the external systemic interpretation in case of interpretation doubts.

When resolving the problem of the type of the tax base, a reference should also be made to an interpretation of the objectives of provisions. This can serve as a level II of interpretative directive confirming or con-

25 Judgment of the Voivodeship Administrative Court in Rzeszów of 12 April 2007, I SA/Rz 633/06, CBOSA. 
tradicting the results obtained by applying the other methods ${ }^{26}$. It should be noted that for the taxation of non-building structures with real estate tax the legislator has adopted two types of tax bases - the initial value for depreciation purposes and the market value. The relationship between these bases relates to the primacy of their application. It is based on the scheme of the rule and the exception to the rule, i.e. the rule is that the value of the non-building structure for depreciation purposes is adopted as the taxable base. However, when depreciation does not take place (i.e. the non-building structure is not subject to depreciation), the market value of the non-building structure is taken as the base. Additionally, the process of determining and verifying the tax base is relatively straightforward for both the taxpayer and the authority in case of determining the depreciation value. However, the determination of the market value is much more complicated and, in accordance with Article 5(7) of the LTCA, it may involve charging the taxpayer with the costs of an expert's report. The interdependence between the two tax bases for non-building structures makes it possible to conclude that the purpose of the regulation that recognises the market value as the tax basis was to ensure the possibility of making a tax assessment when is impossible to determine a tax base other than the initial value of the fixed asset. However, it is difficult to accept any other category than the market value as the tax base for non-building structure if this value does not exist. This leads to the conclusion that, there is no reason to adopt the market value as a tax base, an act which is intended to guarantee the completeness of the system when it is possible to determine the tax base on the basis of a specific value which constitutes grounds for depreciation write-offs. Therefore, the object of the interpreted provisions favours using the initial value of non-building structure as the tax base in case of depreciation write-offs, including those for accounting purposes.

In conclusion, there is no justification for adopting the market value as the tax base in a situation where balance sheet depreciation write-offs are made on the non-building structures. The tax base is then the initial

26 See B. Brzeziński, Wstęp do nauki..., p. 193-194 and 209. 
value of the fixed asset when this value is adopted for the purposes of that depreciation. This point also correctly reflects the necessary connections between tax law and balance sheet law. Moreover, it seems that the legislator, when determining the tax base for non-building structures, i.e. the element of the tax structure which in quantitative terms is to present the feature of the structure subject to taxation, taking into account the fact that this structure is a fixed asset used for business activity, should refer to the provisions of the balance sheet law. Although the main objectives of tax regulations and balance sheet regulations differt ${ }^{27}$ an interpretation of tax regulations should not overlook the manner in which the mandatory reflection of economic phenomena and processes takes place in the accounting records kept by the taxpayer. This is especially needed when the interpreted concepts originate from the regulation for balance sheet purposes.

It should be emphasised that the adopted position is inconsistent with the jurisprudence of administrative courts, which (considering the decisions of the courts of second instance) may be viewed as dominant. Therefore, de lege ferenda, an amendment of the provisions of the Act on Local Taxes and Charges should be postulated where the same tax depreciation and balance sheet depreciation effect will unambiguously impinge on the need of determining the tax base for non-building structures.

\section{The tax base in the capitalisation of "indirect costs" not related to a non-building structure in the value of a fixed asset}

A reference to another issue related to the tax base in real estate tax for non-building structures depends on the understanding of the term "depreciation value". This term concerns the capitalisation of the so-called indirect costs in the initial value of a fixed asset - a non-building structure, which is subject to taxation. Such costs are not directly and exclusively

\footnotetext{
With regard to the tax function of accounts see: B. Brzeziński, Informacja i dokumentacja w prawie podatkowym [in:] B. Brzeziński (ed.), Prawo podatkowe. Teoria. Instytucje. Funkcjonowanie, Toruń 2009, pp. 297-298.
} 
related to the non-building structure itself (e.g. costs of legal, economic, or architectural services related to the investment which include the nonbuilding structure, also referred to as "investment-related costs"). However, they are included by the taxpayer in the initial value for depreciation purposes. It should be stressed that an accounting of such costs results from the accounting needs and it is caused by the nature of these costs, as they are associated with the entire investment process, because it is not possible to uniquely qualify them to create a particular fixed asset. The problem with determining the tax base for non-building structures in this situation is connected with the fact that according to Article 4(5) of the LTCA if no depreciation write-offs are made on the non-building structures or their parts, the tax base is constituted by their market value as determined by the taxpayer. The initial value of a fixed asset for depreciation purposes includes "indirect costs" and non-building structures subject to real estate taxation are not separated fixed assets subject to depreciation, but they are included in the initial value of the entire complex fixed asset, which is not a non-building structure. Thus, the problem arises as to whether it is appropriate to tax non-building structures on the basis of their market value. It is disputable whether all "indirect costs" should be excluded from the value of a fixed asset for the purposes of determining the tax base of a non-building structure, if the tax base is deemed to be the value for depreciation purposes.

With respect to the issue of the type of a tax base, one should refer to established and undisputed arguments from administrative court rulings, according to which the determination of the market value as a tax base may concern only the situation when the non-building structure is not and has not been depreciated ${ }^{28}$. On the other hand, Article 4(5) of the LTCA applies to non-building structures from which no depreciation write-offs are made at all, i.e. structures in relation to which depreciation write-offs have never been made. When interpreting the regulations, it should also be taken into account that Article 4(5) of the LTCA is an exception to

28 Judgment of the Voivodeship Administrative Court in Olsztyn of 21 November 2013, I SA/Ol 657/13, CBOSA. 
Article 4(1)(3) of the LTCA, in which the situation of currently depreciable and depreciated non-building structures has been regulated ${ }^{29}$.

Although the above view might not be directly related to the problem of capitalising indirect costs in the value of a fixed asset, it should be noted that the courts based their decision on the litteral wording of Article 4(5) in conjunction with Article 4(1)(3) of the LTCA. Judges emphasise that "the structure is not depreciated". We should also share the view that the interpretation of Article 4(5) read in conjunction with Article 4(1)(3) of the LTCA should be based on the assumption that Article 4(5) of the LTCA is an exception to the rule and, as a result, there is a significant limitation as to the scope of its interpretation. This is because according to the principle exceptions are not interpreted broadly. The case-law, on the other hand, points out that linguistic interpretation takes precedence and that the provisions of tax law must be interpreted in the first place ${ }^{30}$ taking into account their literal wording among the rules of interpretation of tax law. In addition, it is important that exceptions should not be interpreted broadly - exceptiones non sunt extendendae ${ }^{31}$. Therefore, the referenced rules prescribe that the meaning of a legal norm should not be unduly extended beyond what follows from the linguistic meaning of the regulation $^{32}$. This view leads to the conclusion that the non-building structure is depreciated and therefore its market value cannot be its tax base if the initial value of a complex fixed asset which comprises a non-building structure includes “indirect costs”.

On the other hand, with respect to the issue of the type of a tax base to be used for non-building structures in the situation of capitalising the "indirect costs" in the initial value, two divergent jurisprudence lines in administrative courts can currently be distinguished.

29 Judgment of the Voivodeship Administrative Court in Kraków of 14 September 2010, I SA/Kr 845/10, CBOSA.

31 L. Morawski, Zasady wykładni prawa, Toruń 2010, p. 193 et seq.; M. Zieliński, Wykładnia prawa. Zasady, reguły, wskazówki, Warszawa 2008, pp. 248-249.

32 As regards the possibility of diverging from the result of linguistic interpretation, see B. Brzeziński, Wykładnia prawa podatkowego, Gdańsk 2013, pp. 25-26. 
The first line is represented by the judgment of the Voivodeship Administrative Court in Rzeszów of 7 May $2019^{33}$. In this judgment it was rigorously recognised that it is not possible to determine that value differently from the value adopted by the taxpayer for income tax purposes, even if irregularities are found in determining that value, since the tax base is the initial value of a fixed asset and the authority is bound by the value determined by the taxpayer for the purposes of depreciation in income tax. The court pointed out that the provisions of the Act on Local Taxes and Charges do not allow a taxpayer to determine the initial value of a non-building structure differently for the purposes of income taxes and real estate tax - when the taxpayer assumes the market value of a nonbuilding structure. It was also pointed out in the judgment that the authority competent in the real estate tax case has no authority to interfere in the value for depreciation purposes, which is a sphere reserved for another tax authority. Thus, it is not possible to exempt the values chosen by the taxpayer from the value of the tax base for real estate tax, if the later value includes "indirect costs".

A completely different line of jurisprudence is represented by the judgment of the Voivodeship Administrative Court in Gliwice of $5 \mathrm{Ju}-$ ly $2018^{34}$. According to this judgment the tax authority is obliged to determine the tax base, so that it refers only to the object of taxation which is a non-building structure. In the court's opinion, it is necessary to verify the inclusion of the initial value of complex fixed assets which constitute a collection of non-building structures and facilities that are not nonbuilding structures in the tax base, by adjusting the tax base in such a way that the base includes only the initial values of non-building structures. However, the tax authority is obliged to demonstrate that they constitute the cost of creating that non-building structure when it include a specific rela-

33 I SA/Rz 157/19, CBOSA; similarly the Supreme Administrative Court in the judgment of 12 January 2016, II FSK 2244/15, CBOSA.

34 I SA/Gl 357/18, CBOSA; similarly, Supreme Administrative Court judgment of 24 November 2017, II FSK 1981/17, CBOSA. 
tive value of indirect costs in the tax base. Therefore, any other "indirect costs" are to be excluded from the tax base for the non-building structure ${ }^{35}$.

In assessing the above standpoints, it should be concluded that there is no legal basis for including in the tax base for a non-building structure those "indirect costs" or any other values which do not constitute its depreciation value, as they are not related to the non-building structure. The formalistic approach that refers to the inability to change the tax base in a real estate tax by reducing the initial value by "indirect costs" is not justified in the mutual relationships of tax regulations and balance sheet regulations. In this case, what is included in the initial value of a fixed asset results only from accounting requirements and does not reflect economic reality. If the subject of real estate tax is a non-building structure and if the initial value of this non-building structure is the taxable base, then the requirements for balance sheet purposes should not determine the increase of this base by those values which are not related to the nonbuilding structure itself.

\section{Final conclusions}

The conducted analysis leads to the conclusion that the provisions regulating the tax base in a real estate tax with regard to non-building structures, like other provisions of the Act on Local Taxes and Charges, are ambiguous. This means that although it seems that the main problem for a real estate taxpayers is to decide whether they are within the subjective-objective scope of the tax (what is often challenging in case of non-building structure taxation as it requires highly specialised knowledge which takes into account institutions of other branches of $\operatorname{law}^{36}$ ), but another complicated problem is the establishment of the correct tax

35 See also the concept of "correctinng the depreciation value" - W. Morawski, Podstawa opodatkowaniu budowli będq̨cej częściq środka trwałego - między wartościq rynkowq a wartościq początkowq środka trwałego, „Przegląd Podatkowy” 2014, No 6, p. 18 et seq.

36 See the views on the understanding of the term "non-building structure” presented in the judgments of the Constitutional Tribunal: of 13 November 2011, P 33/09 and of 13 December 2017, SK 48/15. 
base. At the same time, the jurisprudence of administrative courts is not helpful, because in the area of non-building structure taxation a farreaching discrepancy is rather common not only in the examples described above. Taking into account the number of potential real estate taxpayers and facilities classified as non-building structures ${ }^{37}$, the problem of the type of tax base seems to be significant enough to require the intervention of a legislator. Thus, the legislator should decide on a transparent scope of linking the regulation of the Act on Local Taxes and Charges with institutions from other acts in this category.

At the same time, the attempt to find more general rules that could guide the legislator in the area of linking tax regulations with institutions of balance sheet law fails. The analysis of the jurisprudence of administrative courts with respect to problems raised in this study allows to conclude that, on the one hand, courts reject the possibility of referring to balance sheet regulations when there are reasonable grounds to take into account the interconnectedness of tax and balance sheet law institutions. On the other hand, the courts see a need to rely on the values resulting from the accounting records. At the same time, the above standpoints seem to disregard the mutual relations between tax law and balance sheet law if the regulations of the real estate tax base do not show any connection with the balance sheet law institutions and if there is no reasonable basis for the interpretation of the regulations to refer to the balance sheet law regulations. There is no doubt that one of the basic functions of tax records kept on the basis of the regulations of the Accounting Act is the registration of information in order to use it to determine the subject and tax base in income taxes ${ }^{38}$. However, this cannot be a reason to claim that accounting regulations should be omitted from the interpretation of ambiguous tax regulations.

37 The analysis of the database of administrative court judgments gives a certain picture, as it indicates over 14 thousand judgments concerning the real estate tax, in which the statement of reasons refers to the term "non-building structure".

38 B. Brzeziński, Prawo podatkowe. Zagadnienia..., pp. 555-556. 


\section{Bibliography:}

Adamiak B., Borkowski J., Mastalski R., Zubrzycki J., Ordynacja podatkowa. Komentarz, Oficyna Wydawnicza „Unimex”, Wrocław 2016.

Brzezicki T., Lasiński-Sulecki K., Łunarski O., Majka P., Morawski W. (ed.), Wantoch-Rekowski J., Podatek od nieruchomości w orzecznictwie sq̨ów administracyjnych. Komentarz. Linie interpretacyjne, Wolters Kluwer Polska, Warszawa 2013.

Brzezicki T., Lasiński-Sulecki K., Morawski W. (ed.), Wantoch-Rekowski J., Ustawa o podatkach i opłatach lokalnych. Komentarz, ODDK, Gdańsk 2009.

Brzeziński B. (ed.), Filipczyk H., Kalinowski M. (ed.), Lasiński-Sulecki K., Masternak M., Morawski W., Nita A., Olesińska A. (ed.), Orłowski J., Prejs E., Pustuł J., Ordynacja podatkowa. Komentarz praktyczny, ODDK, Gdańsk 2015.

Brzeziński B., Dębowska-Romanowska T., Kalinowski M., Wójtowicz W. (ed.), Prawo finansowe, C.H. Beck, Warszawa 1997.

Brzeziński B., Informacja i dokumentacja w prawie podatkowym [in:] B. Brzeziński (ed.), Prawo podatkowe. Teoria. Instytucje. Funkcjonowanie, Wydawnictwo „Dom Organizatora”, Toruń 2009.

Brzeziński B., Prawo podatkowe. Zagadnienia teorii i praktyki, TNOiK, Toruń 2017.

Brzeziński B., Wstęp do nauki prawa podatkowego, TNOiK, Toruń 2003.

Brzeziński B., Wykładnia prawa podatkowego, ODDK, Gdańsk 2013.

Gajl N., Finanse i prawo finansowe, Wydawnictwo Naukowe PWN, Warszawa 1992.

Harasimowicz J., Finanse i prawo finansowe, Państwowe Wydawnictwo Ekonomiczne, Warszawa 1988.

Kurowski L., Wstęp do nauki prawa finansowego, Państwowe Wydawnictwo Naukowe, Warszawa 1982.

Majka P., Podstawa opodatkowania budowli w podatku od nieruchomości - problem rodzaju podstawy opodatkowania [in:] B. Kucia-Guściora, M. Munnich, A. Zdunek, R. Zieliński (ed.), Stanowienie i stosowanie prawa podatkowego w Polsce. Granice opodatkowania, Wydawnictwo KUL, Lublin 2019.

Morawski L., Wykładnia w orzecznictwie sq̨dów, TNOiK, Toruń 2002.

Morawski L., Zasady wykładni prawa, TNOiK, Toruń 2010.

Morawski W., Podstawa opodatkowaniu budowli będq̨cej częściq środka trwałego - między wartościq rynkowq a wartościq poczq̨tkowq środka trwałego, „Przegląd Podatkowy” 2014, No 6, pp. 16-23.

Ostrowski K., Prawo finansowe. Zarys ogólny, Państwowe Wydawnictwo Naukowe, Warszawa 1970. 
Paweł Majka

Radzikowski K., Ciq̨g dalszy sporów o definicję budowli jako przedmiotu opodatkowania podatkiem od nieruchomości - casus elektrowni wiatrowych, „Zeszyty Naukowe Naczelnego Sadu Administracyjnego” 2017, No 5, pp. 37-60.

Weralski M., Finanse publiczne i prawo finansowe, Państwowe Wydawnictwo Naukowe, Warszawa 1984.

Zieliński M., Wykładnia prawa. Zasady, reguły, wskazówki, Lexis Nexis, Warszawa 2008. 